\title{
Metaphorical Patterns in Anthropocene Fiction
}

Rev. June 2019 - preprint version, please cite published version

Marco Caracciolo (marco.caracciolo@ugent.be) ${ }^{1}$

Andrei lonescu (andrei.ionescu5891@gmail.com)

Ruben Fransoo (ruben.fransoo@ugent.be)

Ghent University

Department of Literary Studies

Blandijnberg 2

9000 Ghent

Belgium

\section{Abstract}

This article explores metaphorical language in the strand of contemporary fiction that Trexler (2015) discusses under the heading of 'Anthropocene fiction' - namely, novels that probe the convergence of human experience and geological or climatological processes in times of climate change. Why focus on metaphor? Because, as cognitive linguists working in the wake of Lakoff and Johnson (1980) have shown, metaphor plays a key role in closing the gap between everyday, embodied experience and more intangible or abstract realities-including, we suggest, the more-than-human temporal and spatial scales that come to the fore with the Anthropocene.

In literary narrative, metaphorical language is typically organized in coherent clusters that amplify the effects of individual metaphors. Based on this assumption, we discuss the results of a systematic coding of metaphorical language in three Anthropocene novels by Margaret Atwood, Jeanette Winterson, and lan McEwan. We show that the emergent metaphorical patterns enrich and complicate the novels' staging of the Anthropocene, and that they can destabilize the strict separation between human experience and nonhuman realities.

\section{Introduction}

In a World Wildlife Fund campaign for climate change created by Belgian design studio BBDO, we see the familiar image of a wafer cone topped with melting ice cream. However, the scoop of ice cream was digitally modified to look like the Earth, with clouds and a large swathe of the Asian continent clearly visible. ${ }^{2}$ This is a striking visual metaphor for anthropogenic climate change: the melting ice cream stands for the Earth's diminishing polar caps. In the visual as well as in the linguistic domain, the use of metaphorical language in climate change discourse is not surprising. In philosopher Dale Jamieson's words, '[climate] change poses threats that are probabilistic, multiple, indirect, often invisible, and unbounded in space and time. Fully grasping these threats requires scientific understanding and technical skills that are often in short supply' (2014: 67). The intangibility of climate change calls for metaphorical language that is able to translate scientific models into concrete, affect-laden imagery. The vast majority of humans will never experience the melting of polar ice directly-although they may experience its devastating effects. BBDO's visual metaphor offers a human-scale equivalent for the abstract causality involved in rising sea levels. The image takes on a sense of urgency as it evokes childhood memories of melting ice cream; it implies that humanity is rapidly-and childishly-consuming the limited resources of the planet. 
So-called 'conceptual metaphor theory' in the wake of Lakoff and Johnson's (1980) work is particularly well equipped to deal with a visual representation along these lines (see Grady, 2007). As Semino puts it:

Cognitive metaphor theorists emphasize that target domains typically correspond to areas of experience that are relatively abstract, complex, unfamiliar, subjective or poorly delineated, such as time, emotion, life or death. In contrast, source domains typically correspond to concrete, simple, familiar, physical and welldelineated experiences, such as motion, bodily phenomena, physical objects and so on (2008: 6).

This is precisely what happens in BBDO's visual metaphor, which brings together an abstract target (scientific models of climate change) and a directly perceptible, quotidian source (the melting ice cream), with the source being used to illuminate the target and make it more intelligible. Steen, another metaphor theorist, calls this the 'perspective-changing' function of metaphor: 'I propose that a metaphor is used deliberately when it is expressly meant to change the addressee's perspective on the referent or topic that is the target of the metaphor, by making the addressee look at it from a different conceptual domain or space, which functions as a conceptual source' (2008: 222).

Societal and scientific discourse on climate change makes extensive use of metaphorical language (see Nerlich and Jaspal, 2012; Skinnemoen, 2009). Think about the phrase 'greenhouse effect,' which equates the action of certain gases in the Earth's atmosphere to heat retention in a human-made structure. Once such metaphors become conventional, they tend to lose their affective and perspective-changing value: as part of scientific language, 'greenhouse effect' evokes none of the emotional associations of the melting ice cream visual metaphor. This is where literature may offer a useful resource for climate change discourse more generally. Literature has long been associated with stylistic foregrounding - that is, unconventional rhetorical devices, including creative metaphor, that depart from everyday language use and therefore promise to revitalize it (Miall and Kuiken, 1994; Short, 1996: 9-13). Goatly's statistical survey confirms that 'active' (i.e., unconventional) metaphors are more frequent in literary genres such as novels and poems than in other discourse types (see Goatly, 2011: 320-326). Arguably, these creative metaphors are particularly effective at exploiting the perspective-changing potential of metaphor in general (Caracciolo, 2017). Because the combination of source and target domain is novel and emotionally impactful, readers' viewpoint on the target is more likely to be affected by literary metaphors than by more conventional ones. ${ }^{3}$

Taking these ideas as a point of departure, this article offers a systematic analysis of metaphorical patterns in three novels that grapple with the spectre of an ecological catastrophe: Margaret Atwood's Oryx and Crake (2003), Jeanette Winterson's The Stone Gods (2007), and lan McEwan's Solar (2010). These novels belong to the macro-genre that Trexler (2015) has named 'Anthropocene fiction,' where 'Anthropocene' is the term coined by chemist Paul Crutzen in the early 2000s for the current geological era: one in which humankind has become a quasi-geological agent capable of shaping the climate future of our planet (Crutzen and Stoermer, 2000). For Trexler, who builds on current work in ecocriticism, Anthropocene fiction stages and questions humankind's interrelation with the nonhuman realities of the ecology, the climate, and the geological history of our planet. This kind of fiction shows the human and the nonhuman to be intimately bound up, so that it is no longer possible to see humankind as metaphysically privileged (see also Grusin, 2015).

This article argues that metaphor is a uniquely powerful tool in revealing this interrelation, by bridging human experience and a wide gamut of nonhuman realities, such as the life of animals, the 
dynamics of ecosystems, or climatological and geological processes. The melting Earth visual metaphor operates in this way: it presents global warming as a process in which human agency (expressed by the familiar image of the ice cream) is inextricably bound up with the more-thanhuman (the planet). Likewise, in the verbal domain, metaphor can challenge dualistic distinctionsfor instance, between human agents and supposedly inert nonhuman objects - that are built into language itself. As Goatly puts it, 'metaphor is, par excellence, the means of de/reconstructing common-sense ordinary language categories' (1996: 557). Literary fiction holds particular promise in this respect, in that it can enhance the defamiliarizing power of metaphorical language by deploying clusters of semantically related metaphors (for detailed discussion, see Semino, 2008: 24-25). These 'extended' metaphors are conceptually and affectively resonant in ways that would be difficult to achieve through a single metaphorical mapping. Put otherwise, metaphors in literary narrative can coalesce into what Martens and Biebuyck (2013) call a metaphorical 'paranarrative,' which complicates and extends the meanings at play in a plot. If, as we posited above, Anthropocene fiction probes the divide between human societies and the nonhuman world, metaphorical paranarratives can modulate the stakes and effects of such probing. In our approach to the three novels we focus on the emergence of metaphorical paranarratives and their interaction with other, non-metaphorical narrative devices. Our core hypotheses are, thus, that creative metaphorical language is central to the anti-anthropocentric project of Anthropocene fiction; and that, conversely, the import of metaphorical patterns can only be understood in the context of broader narrative strategies, which we examine through close engagement with the novels by Atwood, Winterson, and McEwan. Via-respectively-their irony, temporal and thematic loops, and exploration of grotesque embodiment, these novels serve as blueprints for complexifying and deepening everyday discourse on climate change.

In a recent discussion of metaphor and climate change, David Ritchie points to the dangers of metaphors becoming too entrenched in the language of both pro-environmental politicians and climate change sceptics. For Ritchie, recurring metaphorical phrases such as global warming as a 'time bomb' or 'alarmist computer models' lead to the polarization of the debate: 'the dramatic metaphorical stories used by advocates on each side of the debate ... are likely to be ignored, discredited, or dismissed by those who are convinced of the opposite position' (2017: 214). The multiplicity of the metaphorical mappings we reveal across the three novels offers an illustration of how literary fiction can resist this reification and conventionalization of metaphor. Our analysis demonstrates the richness of metaphor's engagement with the nonhuman in the context of literary fiction-a richness that takes a different form in each of the three case studies, reflecting the specifics of the interaction between metaphorical strategies, style, and narrative. These complexities, we claim, channel humankind's multifaceted entanglement with the nonhuman more adequately and insightfully than the 'dramatic' (but largely conventional) 'metaphorical stories' of contemporary politics.

We take on board the notion-central to conceptual metaphor theory-that metaphorical language involves a specific 'orientation,' from a source to a target domain. The target is the focus of the metaphor-the person, object, or situation we seek to shed new light on-while the source is the person, object, or situation that is being used to reveal an aspect of the target. Potentially, this orientation implies a hierarchical or at least an evaluative relation: for instance, 'that man is a dog' has vastly different connotations from 'that dog is a man.' The mapping from an animal (source) to a human (target) in the first sentence is demeaning and disempowering, while the mapping with the opposite orientation (human source, animal target) works towards collapsing the difference between human and animal life. This is but an extremely simple example of how the orientation of metaphor influences meaning generation. The novels we analyse over the next pages are much 
more sophisticated in their use of orientation, based on two factors: whether the human functions as source or target of the metaphor; and how each metaphorical mapping interacts with the larger stylistic and narrative context, including other metaphorical clusters.

In our view, the flexibility of conceptual metaphor theory in the Lakoff and Johnson tradition is particularly well suited to account for the dynamic interaction between narrative and clusters of metaphorical language. In a systematic discussion of this interaction, Popova (2015: 95-115) also builds on Lakoff and Johnson's work to account for metaphor's 'specific contributions to the causal structuring of a story' (2015: 113) - what we've referred to as the 'paranarrative.' Popova argues against newer approaches to the study of metaphor, particularly Fauconnier and Turner's (2002) 'blending theory,' suggesting that the concept of blending is too broad-ranging to capture the complex interplay of narrative and metaphorical language. Fauconnier and Turner posit that metaphors are not simple mappings between conceptual domains but operate via the integration of these domains, which takes place in a mental space that Fauconnier and Turner call a 'blend.' While Popova's objections to blending theory are substantive, our decision to stick with conceptual metaphor theory is based on methodological considerations. Blending is convincingly exemplified by the coherent metaphorical scenarios scrutinized by Fauconnier and Turner, but it is far more difficult to observe in a systematic analysis of a relatively large corpus: most of the time, the metaphorical mappings we discuss display a specific orientation without resulting in a global blend. The concept of 'blending' thus makes concrete metaphor analysis more cumbersome than conceptual metaphor theory, detracting from the heuristic value of the metaphor identification exercise we perform in this article. In the next two sections we expand on our selection of this corpus and on issues of methodology.

\section{The Corpus}

The three novels we analyse in this article are significant works pertaining to Anthropocene fiction; all of them have won critical acclaim and have been discussed from an ecocritical perspective (Garrard, 2013; Ionescu, 2017; Merola, 2014; Snyder, 2011; Zemanek, 2012). The first instalment in the popular MaddAddam series, Atwood's Oryx and Crake envisages a dystopian world in which humanity is wiped out by a mysterious epidemic. As we discover in the course of the novel, this virus was synthesized in a lab, as the combined result of deranged science and corporate greed. The way in which the landscape is altered by human exploitation-and, later, by the disappearance of human beings - resonates with present-day anxieties about climate change. Despite this post-apocalyptic gloom, Atwood's narrative is highly readable and rich in irony as it traces the backstory of its protagonist, who initially appears to be the last human left on Earth.

Winterson's The Stone Gods eschews linearity in favour of mythical overtones. Winterson's approach is also more self-consciously literary than Atwood's: for instance, the novel builds on a large number of intertextual references to Daniel Defoe's Robinson Crusoe as well as John Donne's poetry. The Stone Gods suggests that every civilization is bound to cause its own demise through the mindless exploitation of natural resources, in a loop that has been repeated (and will be repeated) countless times in cosmic history. Billie, the narrator and protagonist, experiences this cyclicity first-hand as she is sent to a distant planet, known as Planet Blue, to recreate the civilization that is failing on Earth.

Finally, McEwan's Solar paints a largely satirical portrait of its protagonist, a Nobel prize-winning physicist. The more-than-human scale of climate change here serves to throw into sharp relief the pettiness of a scientist more interested in women and junk food than in scientific problems. Yet the 
novel succeeds in conveying the deep interrelation between the climate, politics, and the personal lives of the scientists working to understand and potentially prevent climate change.

While certainly not exhaustive, these novels are representative of three different strands in Anthropocene fiction: first, work that grows out of science fiction and retains a clear connection to this genre (Atwood's Oryx and Crake; other examples include Paolo Bacigalupi's The Windup Girl and Kim Stanley Robinson's Forty Signs of Rain); second, work that reflects a mainstream 'literary' novelist's engagement with dystopian motifs (Winterson's The Stone Gods; other examples include Cormac McCarthy's The Road and Colson Whitehead's Zone One); and, finally, work by major novelists that explores human-nonhuman entanglements in a realistic setting (McEwan's Solar; other examples include Barbara Kingsolver's Flight Behaviour and Richard Powers's The Echo Maker). Our three case studies thus exemplify the complex positioning of Anthropocene fiction in the landscape of the contemporary novel.

\section{Methodology}

In our analysis of metaphorical language in the three novels we followed Kimmel's (2008) approach, which combines qualitative coding with computer-aided analysis. However, unlike Kimmel, and in accordance with the theoretical agenda outlined in the introduction, we restricted our focus to a subset of metaphors: namely, metaphorical language that stages the entanglement of human life and nonhuman realities. In order to operationalize this idea, we identified three semantic domains that feed into the umbrella concept of the nonhuman: inanimate objects and structures (to which we assigned the code O); living nonhuman creatures and biological processes in living creatures (coded as LN); and inanimate natural elements and processes (such as geological or topographical features of the landscape, meteorological phenomena, and so on; coded as W, for 'world'). ${ }^{4}$ The authors proceeded to identify all metaphorical expressions in the novels that involve at least one of these categories. The identification was performed at sentence, not at lexical, level: if semantically related metaphors occurred in the same sentence, they were considered as one metaphorical unit in order to avoid excessive fragmentation in the data. ${ }^{5}$ Metaphors proper as well as similes were taken into account, based on the assumption that they both rely on the same cognitive principle of 'mapping' or comparison across semantic domains (Michael et al., 2005). Conventional metaphors (e.g., 'her voice was as bright as ever'; McEwan, 2010: 11) were not taken into account, unless they interacted with the surrounding text in a way that significantly undercut their conventionality. The rationale for this choice was that, as explained in the introduction, creative metaphors hold the greatest potential for unsettling entrenched notions of human separation from the nonhuman world, especially via their emotional impact. A metaphor was considered conventional when it was judged to be in line with everyday language use, for instance because the metaphorical meaning already appears in a standard dictionary definition of the term (as in the case of 'bright' = 'distinct and vibrant') ${ }^{6}$

In a further step, we coded these metaphorical expressions by assigning the following tags in addition to the already mentioned O, LN, and W: LH (for 'living human') for references to persons, parts of the human body, or biological processes occurring in the human body; A for abstract concepts such as those associated with social practices (e.g., religion or art) or institutions (e.g., politics or marriage); and $\mathrm{P}$ for psychological states (sensations and feelings, or cognitive functions such as memory or the imagination). For instance, the sentence '[the women Jimmy encountered] were so emotionally starved even [he] avoided them as if they were quagmires,' from Oryx and Crake (Atwood, 2003: 292), was coded as LH and W on account of the final simile 'as if they were quagmires,' which compares human beings (LH) to a natural landscape (W). By contrast, the equally metaphorical expression 'emotionally starved' was not tagged because it only involves a comparison 
between biological processes in the human body (LH) and psychological experience (P), and thus does not address the nonhuman in any significant way.

We can see these codes as falling on two different sliding scales. The first measures conceptual distance from the human world: $L H, A$, and $P$ are central to this world, while $L N$ and $W$ point to a nonhuman alterity (in the form of other animal species, $\mathrm{LN}$, or inanimate natural processes, $\mathrm{W}$ ). Objects ( 0 ) fall halfway between these conceptual poles, in that they occupy a more ambiguous position: they are closely bound up with human cultures, but they can also serve to destabilize anthropocentric worldviews, especially as far as advanced technology (e.g., artificial intelligence) is concerned. Posthumanist thinking, for instance, focuses on technological artefacts as a challenge to traditional humanism (see Hayles, 2017; Wolfe, 2010). For this reason, we consider objects 'nonhuman' for the purpose of quantifying metaphor usage in the next section; however, the ambivalent role of human-made objects is more fully reflected in our case studies. An alternative way of conceptualizing the relationship between these codes is via the so-called 'animacy hierarchy' (Croft, 2002: 130) or 'animacy scale' (Yamamoto, 1999: 9-10), which ranks nouns on the basis of the degree of animacy (or sentience) they imply: LH and $\mathrm{P}$ involve a maximum of animacy, nonhuman animals (LN) display some degree of animacy, while objects, natural processes, and abstract concepts display none. Yamamoto notes that this scale is in itself 'a product of anthropocentric human cognition' (1999: 9) as well as-we may add-of entrenched cultural assumptions in a Western context. Metaphorical language can unsettle these assumptions by ascribing animacy and even agency to objects and processes normally thought of as inanimate.

For each of the relevant metaphorical expressions in the corpus novels, a target and a source domain were identified, and the orientation of the metaphorical mapping was thus established (in the case of 'as if they were quagmires,' this mapping was represented as ' $\mathrm{W} \rightarrow \mathrm{LH}$,' meaning that $\mathrm{W}$ is the source of the metaphor, $\mathrm{LH}$ is the target domain). The main limitation of this approach is that it forces metaphorical expressions into a source-target grid and does not account for ambiguity or additional meanings created by the context. For instance, in The Stone Gods we read the following: 'Had I lordship of the Universe I should roll men like marbles in the pan of space' (Winterson, 2009: Kindle Locations 1973-1974). 'Roll men like marbles' is a simile of the form O $\rightarrow \mathrm{LH}$, while 'pan of space' is a metaphor $\mathrm{O} \rightarrow \mathrm{W}$. However, this tagging does not reflect the fact that, in the reader's experience, the references to the universe and space confer a cosmic quality to the 'men as marbles' simile as well. We decided not to code these supplemental connotations, because they would have greatly complicated the task of quantifying the metaphorical expressions across the novels. But we take into account these ambiguities fully in the qualitative analysis that follows. The quantitative analysis is thus to be seen as a heuristic tool, supporting our interpretive engagement with the novels rather than replacing it entirely.

\section{Results}

Tables 1 and 2 present the absolute and relative frequency of the main metaphorical types across the three novels, and the relative frequency of each type per novel. ${ }^{7}$ This means that, for instance, $\mathrm{O}$ $\rightarrow$ LH metaphors occur 145 times in the corpus, representing $13.44 \%$ of the total metaphor usage across the novels. $\mathrm{O} \rightarrow \mathrm{LH}$ mappings amount to $15.22 \%$ of the metaphors we identified in Oryx and Crake, $12.80 \%$ of the metaphors in The Stone Gods, and $12.20 \%$ of the metaphors in Solar. As pointed out in the previous section, only mappings that involve nonhuman objects $(0)$, animals, plants, and organic processes (LN), or natural elements (W) are listed. Table 1 presents the mappings with human-related targets ( $\mathrm{LH}, \mathrm{A}$, and $\mathrm{P})$, while Table 2 focuses on nonhuman-related targets (W, LN, and O). 


\begin{tabular}{|l|r|r|r|r|r|}
\hline $\begin{array}{l}\text { Metaphorical } \\
\text { types: } \\
\text { human as } \\
\text { target }\end{array}$ & $\begin{array}{l}\text { AF } \\
\text { across } \\
\text { the } \\
\text { novels }\end{array}$ & $\begin{array}{l}\text { RF } \\
\text { across } \\
\text { the } \\
\text { novels }\end{array}$ & $\begin{array}{l}\text { Oryx and } \\
\text { Crake (RF } \\
\text { per novel) }\end{array}$ & $\begin{array}{l}\text { The Stone } \\
\text { Gods (RF } \\
\text { per novel) }\end{array}$ & $\begin{array}{l}\text { Solar (RF } \\
\text { per novel) }\end{array}$ \\
\hline $\mathrm{O} \rightarrow$ LH & 145 & 13.44 & 15.22 & 12.80 & 12.20 \\
\hline LN $\rightarrow$ LH & 131 & 12.14 & 19.02 & 9.60 & 7.44 \\
\hline $\mathrm{O} \rightarrow \mathrm{A}$ & 101 & 9.36 & 8.15 & 5.60 & 14.88 \\
\hline $\mathrm{O} \rightarrow \mathrm{P}$ & 86 & 7.97 & 13.59 & 1.60 & 8.93 \\
\hline $\mathrm{W} \rightarrow \mathrm{LH}$ & 53 & 4.91 & 2.17 & 8.27 & 4.17 \\
\hline $\mathrm{W} \rightarrow \mathrm{P}$ & 40 & 3.71 & 4.08 & 1.87 & 5.36 \\
\hline $\mathrm{W} \rightarrow \mathrm{A}$ & 35 & 3.24 & 1.90 & 2.13 & 5.95 \\
\hline LN $\rightarrow$ P & 24 & 2.22 & 4.62 & 1.07 & 0.89 \\
\hline LN $\rightarrow$ A & 18 & 1.67 & 1.63 & 0.80 & 2.68 \\
\hline Total & 633 & 58.66 & 70.38 & 43.74 & 62.50 \\
\hline
\end{tabular}

Table 1: Main metaphorical types across the three novels, human as target domain. AF = absolute frequency, RF = relative frequency (in \%).

\begin{tabular}{|l|r|r|r|r|r|}
\hline $\begin{array}{l}\text { Metaphorical } \\
\text { types: } \\
\text { nonhuman } \\
\text { as target }\end{array}$ & $\begin{array}{l}\text { AF } \\
\text { across } \\
\text { the } \\
\text { novels }\end{array}$ & $\begin{array}{l}\text { RF } \\
\text { across } \\
\text { the } \\
\text { novels }\end{array}$ & $\begin{array}{l}\text { Oryx and } \\
\text { Crake (RF } \\
\text { per novel) }\end{array}$ & $\begin{array}{l}\text { The Stone } \\
\text { Gods (RF } \\
\text { per novel) }\end{array}$ & $\begin{array}{l}\text { Solar (RF } \\
\text { per novel) }\end{array}$ \\
\hline $\mathrm{O} \rightarrow \mathrm{W}$ & 71 & 6.58 & 3.53 & 8.53 & 7.74 \\
\hline $\mathrm{O} \rightarrow \mathrm{O}^{8}$ & 47 & 4.36 & 5.16 & 4.53 & 3.27 \\
\hline $\mathrm{LN} \rightarrow \mathrm{W}$ & 42 & 3.89 & 0.82 & 8.27 & 2.38 \\
\hline $\mathrm{O} \rightarrow \mathrm{LN}$ & 40 & 3.71 & 5.16 & 5.07 & 0.60 \\
\hline $\mathrm{LH} \rightarrow \mathrm{W}$ & 37 & 3.43 & 1.09 & 5.33 & 3.87 \\
\hline $\mathrm{LH} \rightarrow \mathrm{O}$ & 29 & 2.69 & 1.36 & 2.67 & 4.17 \\
\hline $\mathrm{LN} \rightarrow \mathrm{O}$ & 26 & 2.41 & 1.36 & 2.93 & 2.98 \\
\hline $\mathrm{W} \rightarrow \mathrm{O}$ & 19 & 1.76 & 2.45 & 1.33 & 1.49 \\
\hline $\mathrm{LN} \rightarrow \mathrm{LN}$ & 17 & 1.58 & 3.26 & 1.33 & 0.00 \\
\hline $\mathrm{A} \rightarrow \mathrm{W}$ & 16 & 1.48 & 0.00 & 3.73 & 0.60 \\
\hline $\mathrm{P} \rightarrow \mathrm{W}$ & 15 & 1.39 & 0.00 & 3.20 & 0.89 \\
\hline $\mathrm{P} \rightarrow \mathrm{O}$ & 11 & 1.02 & 0.00 & 0.80 & 2.38 \\
\hline Total & 370 & 34.30 & 24.19 & 47.72 & 30.37 \\
\hline
\end{tabular}

Table 2: Main metaphorical types across the three novels, nonhuman as target domain. AF = absolute frequency, RF = relative frequency (in \%).

In the following sections, we use these quantitative results to trace the broader metaphorical paranarratives at play in the novels, analysing how metaphorical clusters interact with the plot and other stylistic and narrative strategies.

\section{Objectification and Irony in Oryx and Crake}

The four most frequent mappings in Oryx and Crake ( $\mathrm{LN} \rightarrow \mathrm{LH}, \mathrm{O} \rightarrow \mathrm{LH}, \mathrm{O} \rightarrow \mathrm{P}$, and $\mathrm{O} \rightarrow \mathrm{A}$ ) have $\mathrm{LH}$, $\mathrm{P}$, or $\mathrm{A}$ as a target domain, alone making up more than $50 \%$ of the metaphors we identified in the novel. Because, as argued above, these categories are closely bound up with human subjectivity and culture, this is a strong indication that in this novel the human gravitates towards the target position. This impression is confirmed if we look at The Stone Gods and Solar, where the human also tends to take the target position, but less significantly than in Oryx and Crake (with a relative frequency of $70.38 \%$ vs. $62.50 \%$ in Solar; The Stone Gods has $43.74 \%$ ). Thus, among the most common mappings 
(relative frequency higher than 7\%) in Winterson's and McEwan's novels there is at least one type in which the target is W (O $\rightarrow \mathrm{W}$ and $\mathrm{LH} \rightarrow \mathrm{W}$ in The Stone Gods, $\mathrm{O} \rightarrow \mathrm{W}$ in Solar). On the other hand, in both Oryx and Crake and Solar the most frequent mappings have either $\mathrm{O}$ or $\mathrm{LN}$ as a source domain, with LN ranking first in Atwood's novel.

Here are some examples from Oryx and Crake, one for each of the top four mappings: 'Snowman, please tell us-what is that moss growing out of your face?' (LN $\rightarrow$ LH; Atwood, 2003: 9); 'What she reminded him of at such times was a porcelain sink: clear, shining, hard' ( $\mathrm{O} \rightarrow \mathrm{LH}$; 2003: 36); 'Another baffling item on the cryptic report card his mother toted around in some mental pocket' (O $\rightarrow$ P; 2003: 80); 'the vital arts and their irresistible reserved seat in the big red-velvet amphitheatre of the beating human heart' ( $O \rightarrow A ; 2003: 219)$. The human body, mind ('mental pocket'), and even a core component of human culture (the arts), are objectified or reduced to biological forms (the 'moss') widely seen as inert and therefore object-like. But, as these examples suggest, Atwood's mappings work differently from a common use of objectification, whereby humans belonging to a minority group are relegated to a subordinate role and thus denied autonomy and subjectivity (see, e.g., Papadaki, 2010). In fact, the salient feature of virtually all these mappings is that they 'demote' humans by comparing them to things and objects that rank lower on the animacy scale (such as 'moss,' a 'porcelain sink,' a 'pocket,' or a 'seat'). The effect of this demotion is distinctly ironic and sets Oryx and Crake apart from the other two novels. ${ }^{9}$ We build here on Currie's theory of irony as a form of perspective-taking:

[The] ironist's utterance [is] an indication that he or she is pretending to have a limited or otherwise defective perspective, point of view, or stance $F$, and in doing so puts us in mind of some perspective, point of view, or stance (which may be identical to $\mathrm{F}$ or merely resemble it) which is the target of the ironic comment (2010: 157). ${ }^{10}$

Atwood's metaphors take the perspective of someone equating human subjectivity and culture to inanimate objects, which is evidently a 'defective' point of view insofar as it clashes with ingrained ideas of 'the human' with a capital $h$. The incongruity generated by this conceptual clash is at the root of Atwood's irony, which performs what we may think of self-deprecating humour on a species level: via the objectifying paranarrative, a human author mocks the presumed metaphysical primacy of humankind for the benefit of her human audience.

Perhaps the clearest manifestation of this strategy is a pervasive metaphorical cluster comparing human beings to food (resulting in a loss of animacy). In the final pages of the novel, the protagonist, Snowman, makes a desperate attempt at scavenging the research facility in which the deadly virus was first synthesized. The reason for this risky foray is that Snowman is running out of food, which creates an archetypical narrative situation: food becomes the object of Snowman's quest. At the level of plot, the nonhuman is thus subordinated to the human and instrumentalized. But the metaphorical paranarrative reverses this situation, since the human body is repeatedly turned into the target of metaphorical mappings that use food as the source. For instance, Snowman thinks: '[Like] a horse, his life now depends on [his ability to use his feet to walk]. If he can't walk, he's rat food' (2003: 270). Noteworthy here is the metaphorical progression from LN $\rightarrow$ LH ('like a horse') to $\mathrm{O} \rightarrow \mathrm{LH}$ ('he's rat food'), which performs a two-step demotion of the narrative's human protagonist along the animacy scale: from human being to animate nonhuman creature to inanimate substance. Later, we read that the vultures were 'waiting for him to be meat' (2003: 416), or-in a more elaborate variation, with an element of $\mathrm{P}$-that 'his foot feels like a gigantic boiled wiener stuffed with hot, masticated flesh, boneless and about to burst' (2003: 389). These metaphorical mappings 
serve the ironic purpose of destabilizing the distinction between human flesh and animal meat, thus feeding into the novel's broader critique of anthropocentrism. Furthermore, the metaphors dislodge the human from the agentive subject position that it still retains in the plot. Importantly, the irony implicit in these metaphors is not just the result of a narratorial stance but the reflection of the protagonist's self-deprecating humour, so that Snowman serves as a diegetic embodiment of the anti-anthropocentric worldview articulated by the novel as a whole. ${ }^{11}$

Nowhere does this metaphorical critique become more evident than in the novel's conclusion. Here Snowman manages to escape from the research facility in which his childhood friend, Crake, has concocted the virus that caused humanity's demise. Crake died in the facility, and his bones are still there, 'mingled and in disarray, like a giant jigsaw puzzle' (with an O $\rightarrow$ LH mapping; 2003: 391). Snowman makes his way back to the village inhabited by so-called 'Crakers,' the new human species genetically engineered by Crake to be immortal and immune to the deadly epidemic (but also simple-minded and incapable of sophisticated cultural expression). Upon Snowman's return, the Crakers ask him whether they can meet their creator, whom Snowman has been depicting so far (quite truthfully, at least as far as the Crakers are concerned) as a divine figure. That of the emotionally charged encounter between a creature and its maker is a classic trope of science fiction, going back at least to Mary Shelley's Frankenstein. Atwood gives it an ironic twist: Snowman remembers Crake's bones and remarks that the Crakers are not allowed to meet him, because he has 'turned himself into a plant.' To which one of the Crakers, who eat a vegetarian diet, responds: 'Why would Crake become food?' (2003: 421).

Crake, the scientist who embodies a dream (soon turned into a nightmare) of technological mastery over the nonhuman world, is literally metamorphosed into unrecognizable bones, and symbolically into a plant and mere 'food.' This exchange between Snowman and the Crakers marks the emergence into the novel's plot of the metaphorical paranarrative that questions the distinction between human beings and food, and-more generally - the divide between humans, other life forms, and inanimate objects: Crake himself thus becomes the target of Atwood's ironic narration, just as humankind had been the regular target of the narrator's metaphorical mappings. Unlike Crake, Snowman becomes poignantly aware of the thin line that separates our species from nonhuman realities: remember the simile that captures the experience of his aching foot by comparing it to a 'gigantic boiled wiener' -in itself an image rich in humorous overtones. ${ }^{12}$ Through the persona of the likable, irony-prone protagonist, Atwood's novel offers readers the chance to develop a similar awareness of the continuum between human and nonhuman realities.

\section{Metaphorical Loops in The Stone Gods}

As we observed in the previous section, metaphorical mappings in The Stone Gods present a less linear picture than in Oryx and Crake, where $70.38 \%$ of the metaphors have the human as a target domain. In Winterson's novel, by contrast, that percentage is much lower (43.74\%). Indeed, three of the most frequent types ( $\mathrm{O} \rightarrow \mathrm{W}, \mathrm{LN} \rightarrow \mathrm{W}$, and $\mathrm{LH} \rightarrow \mathrm{W}$ ) place inanimate natural processes in the target position, making up over $20 \%$ of the total mappings. Here are some examples for each of these types: 'The sky exploded in grenades of colour' ( $\mathrm{O} \rightarrow \mathrm{W}$; Winterson, 2009: Kindle Location 3655); 'one star just visible like the bud of a horn' (LN $\rightarrow$ W; 2009: Kindle Location 2291); 'strands of rock, splintered out from the surface like thick plaits of hair' (LH $\rightarrow$ W; 2009: Kindle Location 1011). These passages inscribe visual forms associated with the human body (hair), technology (grenades), or living beings (a horn) into astronomical or geological phenomena. This strategy goes hand in hand with the explicit anthropomorphization of the nonhuman, in relatively common mappings such as $\mathrm{A}$ $\rightarrow \mathrm{W}(3.73 \%)$ and $\mathrm{P} \rightarrow \mathrm{W}$ (3.20\%): for instance, 'there must be planets that are their own mistakesstories that began and faltered' ( $\rightarrow$ W; 2009: Kindle Location 1777), where the abstract notions 
'mistakes' and 'stories' are projected onto planets. A similar case is the ascription of psychological qualities onto inanimate landscapes: 'The petrified forest is there-carbonized tree remains, held in the heat, we don't know how, like a memory' ( $P \rightarrow W$; 2009: Kindle Location 1071) and 'the Pennines that held the towns like a memory' ( $\rightarrow$ $\rightarrow$; 2009: Kindle Location 2468). A $\rightarrow W$ and $P \rightarrow$ $W$ mappings are absent in Oryx and Crake and extremely infrequent $(<1 \%)$ in Solar, highlighting the distinctiveness of Winterson's approach to metaphor. In contrast to Oryx and Crake, in which the objectifying paranarrative tends to collapse the human into nonhuman elements, The Stone Gods makes extensive use of metaphors that 'promote' the nonhuman to a higher position on the animacy scale-that of a minded agent.

One of the most self-conscious uses of this anthropomorphizing strategy builds on the quotation of a line from Donne's poem 'The Sun Rising,' which recurs, like a leitmotif, throughout the novel. The line reads: 'She is all States, all Princes I.' Donne's conceit was to compare his lover to 'all States' (i.e., all countries on Earth), and himself to 'all Princes,' suggesting that their romantic union is as complete and metaphysically sovereign as the planet itself. In terms of the coding system adopted in this article, Donne's metaphor could be construed as $W \rightarrow L H$, since the image of the Earth is leveraged to shed light on the poet's feelings towards his lover. However, Winterson puts a vastly different spin on this metaphor, employing it to characterize not a human lover but an actual planet, known as 'Planet Blue,' a promised land in which humanity could supposedly rebuild civilization from the ashes of the Earth's environmental exploitation. In the following scene, for instance, the narrator is on a spaceship, hurtling towards Planet Blue with a handful of settlers: "To Planet Blue," [the captain] said, raising his glass, and there on the diode screen was the picture of our new world, and underneath: She is all States, all Princes l' (2009: Kindle Locations 962-964; italics in the original). The planet is thus endowed with human-like qualities, which make it worthy of the poet's (and the captain's) love. But this personification is caught in a sophisticated intertextual dance, in which the lover and the planet swap metaphorical positions (W $\rightarrow \mathrm{LH}$ in Donne, $\mathrm{LH} \rightarrow \mathrm{W}$ in Winterson), evoking a sense of circularity between the human and the nonhuman.

In fact, this impression of circularity is consistent with Winterson's metaphor usage in The Stone Gods, where the mappings tend to travel in both directions, from the human to a nonhuman target (47.72\% of the metaphors) and back from the nonhuman to a human target $433.74 \%$ of the metaphors). We have been emphasizing mappings where $\mathrm{W}$ takes the target position so far, but types such as $\mathrm{LN} \rightarrow \mathrm{LH}$ or $\mathrm{W} \rightarrow \mathrm{LH}$ are also present in the novel. In some cases these mappings objectify the human body, introducing an ironic distance comparable to the humour of Atwood's novel: 'All men are hung like whales. All women are tight as clams below' (LN $\rightarrow$ LH; 2009: Kindle Location 343). But more significant are metaphors in which-just as in Donne's poem-astronomical or geological references serve to transfigure and enchant the human body: 'These are men glamorous as comets, trailing fame in firetails' (W $\rightarrow$ LH; 2009: Kindle Location 79). W $\rightarrow$ LH mappings are far more frequent in The Stone Gods (8.27\%) than in Atwood's and McEwan's novels (2.17\% and $4.17 \%$ respectively). Winterson's metaphors appear to seek a balance between the human as source and the human as target, and the result is that the embodied self and the material world meet halfway in the metaphorical paranarrative, as suggested by the symmetry of this passage: 'Kiss me. Your mouth is a cave. This cave is your mouth' (2009: Kindle Location 1880).

Crucially, this loop-like logic extends far beyond the novel's metaphor usage. The Stone Gods embraces a philosophy of history reminiscent of Vico's (1999) cyclical account of the rise and fall of civilizations. In Winterson's novel, this process is determined by the depletion of natural resources and-ultimately-by humanity's greed. This circularity underlies the narrative, in that similar situations and even passages (such as the Donne quotation) recur at different moments in the 
novel's chronology. In an instance of mise en abyme, the novel even recursively (and selfreflectively) contains a version of itself. The narrator claims to have found a manuscript titled The Stone Gods on a train, later adding that she had left it there herself: "What's that?" Spike asked. "It's what I told you about, today, yesterday, when, I don't know when, it seems a lifetime ago. The Stone Gods." "I wonder who left it there?" "It was me." "Why, Billie?" A message in a bottle. A signal. But then I saw it was still there ... round and round on the Circle Line. A repeating world' (2009: 3879-3885; ellipsis in the original). The image of the circle pervades the novel, at multiple levels: diegetic, temporal, and thematic. But only the metaphorical paranarrative reveals the deep significance of this circularity: it holds a mirror up to Winterson's fluidly circular metaphysics, in which the human, embodied subject seeps into, and is at the same time shaped by, the nonhuman realities of geology and the cosmos.

\section{Climate Change, the Body, and Satire in Solar}

The most frequent mapping in Solar is $\mathrm{O} \rightarrow \mathrm{A}$, which is present in the other novels as well, but much less common ( $14.88 \%$ vs. $8.15 \%$ and $5.60 \%$ ). Table 1 reveals that $23.51 \%$ of the novel's total mappings have abstract ideas as a target domain, a considerably higher percentage than in either Oryx and Crake (11.68\%) or The Stone Gods (8.53\%). This tendency clearly goes hand in hand with the fact that the novel's protagonist is a scientist who tends to think in abstract terms. As Elena Semino and Kate Swindlehurst argue in a seminal article (Semino and Swindlehurst, 1996), recurrent metaphorical mappings contribute to the textual evocation of a character's distinctive mind style. Superficially, this would seem to be the case for McEwan's portrait of Michael Beard, the Nobel prize-winning physicist who occupies the foreground of Solar. Yet if we take a closer look at the metaphors deployed by McEwan, it is sometimes hard to tell where the character's bias towards abstract concepts ends and where the narrator's satire begins. Consider, for instance, the following extended metaphor of the $\mathrm{O} \rightarrow \mathrm{A}$ type: 'Theoretical physics was a village, and on its green, by the village pump, Beard still had influence' (2010: 97). This comparison conflates an abstract target (the academic field of theoretical physics) with a human-scale village. The passage reflects Beard's belief that he retains some leverage on his colleagues, despite having made extremely limited contributions to science after the discovery that led to the Nobel prize. However, the use of the village as a source domain is hardly flattering and unlikely to originate in the character's thought processes. In fact, the quotation suggests that theoretical physics, for all its high-flown ambitions, is a parochial world; it thus develops McEwan's critique of scientific institutions and their ability to prevent an ecological catastrophe-one of the novel's main thematic concerns.

Many of McEwan's metaphors belong to this ambivalent grey zone between mind style and satire. Another example foregrounds Beard's uneasy personal life: 'Weren't marriages, his marriages, tidal, with one rolling out just before another rolled in? But this one was different' (2010: 3). Here the target is an abstract idea (Beard's attitude towards marriage, A), the source a natural phenomenon (the tides, W). This metaphorical mapping is far more frequent in Solar (5.95\%) than in Oryx and Crake (1.90\%) and The Stone Gods (2.13\%). In this particular instance, the 'tidal' metaphor would seem to express Beard's jaded understanding of his romantic life on the basis of an analogy with the nonhuman world, and yet the overall effect is mostly humorous, in that it contradicts expectations of long-term stability and commitment associated with marriage. McEwan's satire is thus quite different from the self-deprecating irony of Snowman in Oryx and Crake: while Snowman's ironic comparisons between the human body and food play into Atwood's anti-anthropocentric project, so that the protagonist and the novel appear to be on the same wavelength, McEwan's satire operates to a large extent against the grain of the protagonist. As readers, we have to work out McEwan's 
engagement with climate change while juggling the protagonist's perspective and the novel's satirical overtones.

As we have suggested and critics such as Garrard (2013) have argued in detail, McEwan articulates a critique of scientific institutions, which appear unable to deal with or communicate adequately the scale of anthropogenic climate change. Beard becomes the prime target of this satirical attack. Yetand herein lies the novel's main complexity-McEwan also assigns his protagonist a more positive role, by using his somatic experience as a probe into the nonhuman realities of the climate. The implication is that the body might be capable of addressing the shortcomings of scientific thinking and establishing a connection between humans and the environment. Once again, this work of bridge-building is performed by the metaphorical language that runs through Solar and complicates the narrative of Beard's personal as well as professional life.

Quantitatively, mappings that involve the human body (LH) as either a source or a target are not more frequent in Solar than in our other case studies. But they take on extra interpretive significance as the novel explores Beard's grotesque embodiment. In fact, just as his marriages are 'tidal,' his experience of the body is governed by forces that the novel portrays through a set of $\mathrm{W} \rightarrow \mathrm{LH}$ mappings. Consider this passage, for instance: 'He went home to his flat and lay brooding in the scum-rimmed bath, gazing through steam clouds at the archipelago of his disrupted selfhoodmountainous paunch, penis tip, unruly toes - scattered in a line across a soapy gray sea' (2010: 164). Beard's body is here compared to a landscape, whose jagged features mirror-with a further $\mathrm{W} \rightarrow \mathrm{P}$ mapping-his mental state of dejection and confusion. It is unclear whether this analogy should be attributed to the character or to the narrator; yet, as readers hesitate between Beard's mental perspective and the narrator's possibly satirical intentions, the body itself gains prominence and becomes a focus of attention in its own right. In this way, the novel's ambivalence brings to the fore an embodied channel of communication, perhaps even of communion, with the nonhuman world.

One pivotal scene highlights this embodied connection between Beard and the environment. He is about to deliver a keynote speech at a conference in London, addressing an audience of 'institutional investors, pension-fund managers, solid types who would not easily be persuaded that the world, their world, was in danger' (2010: 129). Suddenly, Beard feels sick:

[As Beard] took his place behind the lectern, gripping tightly its edges in both hands, he felt an oily nausea at something monstrous and rotten from the sea stranded on the tidal mudflats of a stagnant estuary, decaying gaseously in his gut and welling up, contaminating his breath, his words, and suddenly his thoughts. 'The planet,' he said, surprising himself, 'is sick.' (2010: 170-171)

The passage builds on an LN $\rightarrow$ P metaphor in which Beard's queasiness is compared to decaying organic matter emerging from the sea, a parallel further extended into the mapping between the recesses of his body and a natural landscape (W $\rightarrow$ LH). Two words, 'oily' and 'contaminated,' denote Beard's experience but inevitably link this landscape to the exploitation of natural resources ('oil,' a word that Beard will use to refer to petroleum a few lines below) and environmental contamination. This complex metaphorical strategy establishes a connection between natural processes and bodily experience, which Beard himself explicitly acknowledges by declaring the planet 'sick' in his opening remark. Here the key phrase is 'surprising himself': the embodied route to the nonhuman bypasses Beard's conscious appraisal of the ecological crisis (which-the novel implies-he never felt strongly about, jumping on the environmentalist bandwagon only out of narcissistic self-interest). 
The link between the planet's metaphorical sickness and Beard's embodiment emerges again in the novel's ending, in which he discovers that the 'reddish brown blotch' (2010: 276) on his wrist is a potentially life-threatening melanoma, described through another $\mathrm{W} \rightarrow$ LH mapping ('a map of unknown territory'; 2010: 276). Through this plot device and the metaphorical patterns that accompany it, the parallel between Beard's body and the ecological crisis comes into the open. This conclusion suggests that Beard is more than a satirical butt in McEwan's critique of the scientific community's shortcomings. The protagonist becomes an unlikely, and to a large extent unsuspecting, embodiment of climate change-where the word 'embodiment' refers to Beard's actual body, not to a merely conceptual or symbolic connection with the environment. By developing a metaphorical paranarrative through the character's somatic experience, McEwan gestures towards an understanding of human-nonhuman entanglements based not on conceptual models, but on affective and embodied resonance.

\section{Conclusion}

In this article we discussed a systematic analysis of metaphorical patterns in three contemporary novels belonging to what Trexler calls 'Anthropocene fiction': Atwood's Oryx and Crake, Winterson's The Stone Gods, and McEwan's Solar. Our core argument was that metaphor is a powerful tool in revealing the complex interrelation between the human and the nonhuman by bridging large-scale processes which are difficult to conceptualize (e.g., the dynamics of ecosystems, climatological and geological processes) with human embodied experience. Moreover, following Martens and Biebuyck (2013), we claimed that literary narratives tend to deploy clusters of semantically related metaphors coalescing in 'paranarratives' which often conceptually and affectively complicate and expand the meanings emerging from plots and narrative structures.

In order to identify these metaphorical patterns in our data we employed a combination of qualitative coding and computer-aided descriptive statistics. We created six categories, three of them dealing with nonhuman realities (objects and structures $(0)$, living nonhuman creatures and biological processes (LN), and natural elements and processes (W)) and the other three with human embodiment and experience (the human body and biological processes occurring in the body (LH), abstract concepts $(A)$, and psychological states $(P))$. We coded all metaphors involving a nonhuman element as target or source and used our quantitative results to trace the paranarratives operating in the novels; further, we analysed how these paranarratives interact with narrative and thematic strategies.

In the case of Atwood's novel, our results indicated that although the human gravitates to a central position (by being the target of $70.38 \%$ of the metaphors), it is nevertheless ironically devalued and undermined by being continuously compared to objects (including, most poignantly, food). Thus, even though at the level of the novel's plot the human maintains its centrality, the underlying paranarrative stages an anti-anthropocentric worldview, questioning clear-cut distinctions between the human species and nonhuman realities.

Winterson's novel, on the other hand, appears to seek a balance between the human as source and the human as target in its metaphors, and stages a circular metaphysics in which human subjectivity is conceptualized as both infiltrating nonhuman realities such as geology or the cosmos (an aspect revealed by metaphorical clusters where the nonhuman is anthropomorphized) and being inherently shaped by them (in metaphors where astronomical and geological references are used to enchant and transfigure the human body). Thus, the metaphorical paranarrative evokes a sense of circularity between the human and the nonhuman, feeding into-and reinforcing-the circularity pervading the novel at the level of plot and themes. 
Finally, in McEwan's Solar, the protagonist's grotesque embodiment is satirically used as a channel of communication with the nonhuman realities of climate change. By employing metaphorical paranarratives conceptualizing his body in terms of climatological and geological processes dealing with the increasing (anthropogenic) decay characterizing our planet, McEwan builds a powerful satire against the limitations of scientific institutions (and perhaps of humanity at large) in dealing with the ecological crisis.

As it became clear from these readings, the methodology we employed can systematize the study of metaphorical patterns in narrative by allowing for more precise, statistically grounded comparisons between thematically related texts. Our quantitative analysis of the novels has served not to discount interpretive forms of engagement, but to extend the foothold of interpretation, through a productive back-and-forth between the identification of quantifiable patterns and the close reading of the broader context in which those patterns occur. As discussed in the introduction, one of the tenets of conceptual metaphor theory is that metaphorical language tends to collapse the abstract and intangible into human-scale, embodied interactions with the environment (see, e.g., Turner, 1996). In broad strokes, this is confirmed in our corpus by the high frequency of mappings such as $O$ $\rightarrow \mathrm{A}$ or $\mathrm{O} \rightarrow \mathrm{P}(9.36 \%$ and $7.97 \%$ respectively across the novels), which use human-scale objects as the source domain, more abstract concepts as the target domain. Yet our results show that this tendency can be partly reversed in literary fiction through mappings that leave the human on the side lines ( $\mathrm{LN} \rightarrow \mathrm{W} ; 3.89 \%$ ), use the nonhuman as a source domain ( $\rightarrow \mathrm{LH} ; 4.91 \%$ ), or project the human onto the nonhuman world ( $\mathrm{LH} \rightarrow \mathrm{W} ; 3.43 \%$ ). These mappings may be less frequent in purely statistical terms, but they become salient in interpretation, because they are less predictable than $O$ $\rightarrow \mathrm{A}$ or $\mathrm{O} \rightarrow \mathrm{P}$ associations. These metaphorical expressions involving the nonhuman challenge the anthropocentric set-up of everyday language (as reflected in the animacy scale, for instance) and make a key contribution to the broader critique of anthropocentrism articulated by Anthropocene fiction. Further, the multiplicity and mixed directionality of the metaphors we identified in the three novels explain how literary fiction can challenge established patterns of metaphor usage, going beyond the entrenched language of much political discourse and therefore, potentially, complexifying the reader's imagination of human-nonhuman connection.

Our discussion offers a template for ecocritical approaches to narrative that, like James's (2015) econarratology, aim to go beyond a merely diegetic or thematic level of analysis. We posit that literary metaphor is a formal, stylistic site of negotiation of human-nonhuman entanglements in narrative. Not only can such creative metaphors be quantified and compared systematically across novels (and, potentially, genres and text types), but they afford an opportunity for rethinking our imagination of the nonhuman outside of literary fiction as well. A fuller awareness of the potential of creative metaphor could benefit media discourse and science communication (see, e.g., Dahlstrom, 2014), both of which need more sophisticated and emotionally impactful narratives to convey our precarious position vis-à-vis the nonhuman world.

\section{References}

Atwood M (2003) Oryx and Crake. New York: Random House.

Caracciolo M (2013) Phenomenological metaphors in readers' engagement with characters: The case of Ian McEwan's Saturday. Language and Literature 22(1): 60-76.

Caracciolo M (2017) Creative metaphor in literature. In: Semino E and Demjén Z (eds) Routledge Handbook of Metaphor and Language. London: Routledge, pp. 206-218.

Croft W (2002) Typology and Universals. Cambridge: Cambridge University Press. 
Crutzen PJ and Stoermer EF (2000) The Anthropocene. Global Change Newsletter 41: 17-18.

Currie G (2010) Narratives and Narrators: A Philosophy of Stories. Oxford: Oxford University Press.

Dahlstrom MF (2014) Using narratives and storytelling to communicate science with nonexpert audiences. Proceedings of the National Academy of Sciences 111(4): 13614-13620.

Fauconnier G and Turner M (2002) The Way We Think: Conceptual Blending and the Mind's Hidden Complexities. New York: Basic Books.

Garrard G (2013) Solar: Apocalypse not. In: Groes S (ed.) Ian McEwan: Contemporary Critical Perspectives. London: Continuum, pp. 123-136.

Goatly A (1996) Green grammar and grammatical metaphor, or language and the myth of power, or metaphors we die by. Journal of Pragmatics 25(4): 537-560.

Goatly A (2011) The Language of Metaphors. 2nd ed. New York and London: Routledge.

Grady JE (2007) Metaphor. In: Geeraerts D and Cuyckens H (eds) The Oxford Handbook of Cognitive Linguistics. Oxford: Oxford University Press, pp. 188-213.

Grusin R (ed.) (2015) The Nonhuman Turn. Minneapolis: University of Minnesota Press.

Hayles NK (2017) Unthought: The Power of the Cognitive Nonconscious. Chicago: University of Chicago Press.

Hutcheon L (1994) Irony's Edge: The Theory and Politics of Irony. London: Routledge.

Ionescu A (2017) Narrative strategies of representing the environmental crisis in lan McEwan's Solar. In: Sandten C, Gualtieri C and Pedretti R (eds) Crisis, Risks and New Regionalisms in Europe: Emergency Diasporas and Borderlands. Trier: WVT, pp. 287-304.

James E (2015) The Storyworld Accord: Econarratology and Postcolonial Narratives. Lincoln: University of Nebraska Press.

Jamieson D (2014) Reason in a Dark Time: Why the Struggle Against Climate Change Failed-and What It Means for Our Future. Oxford: Oxford University Press.

Kimmel M (2008) Metaphors and software-assisted cognitive stylistics. In: Zyngier S, Bortolussi M, Chesnokova A and Auracher J (eds) Directions in Empirical Literary Studies. Amsterdam and Philadelphia: John Benjamins, pp. 193-210.

Koller V, Hardie A, Rayson P and Semino E (2008) Using a semantic annotation tool for the analysis of metaphor in discourse. metaphorik.de 15: 141-160.

Lakoff G and Johnson M (1980) Metaphors We Live By. Chicago and London: University of Chicago Press.

Lakoff G and Turner M (1989) More than Cool Reason: A Field Guide to Poetic Metaphor. Chicago and London: University of Chicago Press.

Martens G and Biebuyck B (2013) Channelling figurativity through narrative: The paranarrative in fiction and non-fiction. Language and Literature 22(3): 249-262. 
McEwan I (2010) Solar. New York: Knopf.

Merola NM (2014) Materializing a geotraumatic and melancholy Anthropocene: Jeanette Winterson's The Stone Gods. Minnesota Review 83(1): 122-132.

Miall DS and Kuiken D (1994) Foregrounding, defamiliarization, and affect: Response to literary stories. Poetics 22(5): 389-407.

Michael I, Harding JR and Tobin V (2005) On simile. In: Kemmer S and Achard M (eds) Language, Culture, and Mind. Stanford: CSLI Publications, pp. 123-135.

Nerlich B and Jaspal R (2012) Metaphors we die by? Geoengineering, metaphors, and the argument from catastrophe. Metaphor and Symbol 27(2): 131-147.

Papadaki E (2010) Feminist perspectives on objectification. Zalta EN (ed.) The Stanford Encyclopedia of Philosophy. Available at: https://plato.stanford.edu/entries/feminismobjectification/\#PosPosObj (accessed 8 September 2017).

Popova Y (2015) Stories, Meaning, and Experience. New York: Routledge.

Pragglejaz Group (2007) MIP: A method for identifying metaphorically used words in discourse. Metaphor and Symbol 22(1): 1-39.

Ritchie LD (2017) Metaphorical Stories in Discourse. Cambridge: Cambridge University Press.

Semino E (2008) Metaphor in Discourse. Cambridge: Cambridge University Press.

Semino E and Swindlehurst K (1996) Metaphor and mind style in Ken Kesey's One Flew Over the Cuckoo's Nest. Style 30(1): 143-166.

Short M (1996) Exploring the Language of Poems, Plays and Prose. London: Longman.

Skinnemoen J (2009) Metaphors in Climate Change Discourse. MA thesis. University of Oslo, Oslo.

Snyder KV (2011) 'Time to Go': The post-apocalyptic and the post-traumatic in Margaret Atwood's Oryx and Crake. Studies in the Novel 43(4): 470-489.

Steen $\mathrm{G}$ (2008) The paradox of metaphor: Why we need a three-dimensional model of metaphor. Metaphor and Symbol 23(4): 213-241.

Szerszynski B (2007) The post-ecologist condition: Irony as symptom and cure. Environmental Politics 16(2): 337-355.

Trexler A (2015) Anthropocene Fictions: The Novel in a Time of Climate Change. Charlottesville: University of Virginia Press.

Turner M (1996) The Literary Mind: The Origins of Thought and Language. New York and Oxford: Oxford University Press.

Vico G (1999) New Science. London: Penguin.

Winterson J (2009) The Stone Gods. Boston: Houghton Mifflin Harcourt.

Wolfe C (2010) What Is Posthumanism? Minneapolis: University of Minnesota Press. 


\section{Yamamoto M (1999) Animacy and Reference: A Cognitive Approach to Corpus Linguistics. Amsterdam: John Benjamins Publishing.}

Zemanek E (2012) A dirty hero's fight for clean energy: Satire, allegory, and risk narrative in lan McEwan's Solar.Ecozon@ 3(1): 51-60.

\footnotetext{
${ }^{1}$ This article is based on research funded by the European Research Council (ERC) under the European Union's Horizon 2020 research and innovation programme (grant agreement no. 714166).

${ }^{2}$ See https://www.adforum.com/creative-work/ad/player/49872/ice-cream/wwf.

${ }^{3}$ For further discussion of conventionality and literary metaphor, see Semino (2008: 42-54). Our approach builds on Semino's conclusion that 'creativity ... involves a departure from conventional patterns' (2008: 54) of metaphor usage. Put otherwise, a metaphor is creative when it complicates and challenges a conventional metaphorical association (e.g., 'love is a journey'; see Lakoff and Turner, 1989), or when it is not commonly found in everyday discourse (e.g., 'our planet is melting like ice cream').

${ }^{4}$ The choice of these codes was influenced by the USAS semantic tag set developed by researchers at Lancaster University; see http://ucrel.lancs.ac.uk/usas/. However, the metaphors were identified and tagged manually in order to bring into focus the most salient semantic domains, which would have been difficult to extrapolate from the complex results of an automated analysis (see Koller et al., 2008).

${ }^{5}$ The metaphor identification and the coding were performed independently by two different authors on the whole corpus. After each step, the other authors proceeded to review and discuss the results in order to achieve intersubjective collaboration.

${ }^{6}$ This is consistent with the 'metaphor identification procedure' (MIP) developed by the Pragglejaz Group (2007), where metaphor is operationalized as departure from the dictionary definition of a lexical item.

${ }^{7}$ More specifically, by 'main metaphorical types' we mean mappings whose relative frequency across the corpus is higher than $1 \%$ of the total metaphor usage. We identified 1079 relevant metaphors across the novels: 368 in Oryx and Crake, 375 in The Stone Gods, and 336 in Solar. We used these figures to calculate the relative frequency of the metaphorical types in each novel.

${ }^{8} \mathrm{O} \rightarrow \mathrm{O}$ and $\mathrm{LN} \rightarrow \mathrm{LN}$ mappings may seem unusual, in that both the target and the source belong to the same broad conceptual category ('inanimate objects' and 'biological entities and processes'). However, these expressions still involve cross-domain mapping in terms of the specific semantic fields involved; for example: 'he winds his dirty bedsheet around himself like a toga' (O $\rightarrow 0$; Atwood, 2003: 4).

${ }^{9}$ In fact, in purely quantitative terms objectifying metaphors are not significantly more frequent in Oryx and Crake than in The Stone Gods or Solar. But Atwood's objectification stands out much more because of its interaction with narrative irony, which is highly salient in interpretation.

${ }^{10}$ See also Hutcheon (1994) for a discussion of irony as a strongly evaluative form of perspective-taking.

${ }^{11}$ Bronislaw Szerszynski (2007) explores the link between irony and environmentalism in a way that dovetails with Atwood's approach in this novel.

${ }^{12}$ For more on this use of metaphor to convey the phenomenological qualities of experience, see Caracciolo (2013).
} 